\section{Di- and Triheteronuclear Metal Cluster Anions Containing Transition Metals}

\section{MELVIN L. LUETKENS Jr., FRANCESC TEIXIDOR ${ }^{+*}$ and RALPH W. RUDOLPH ${ }^{++}$}

Department of Chemistry, The University of Michigan, Ann Arbor, Mich. 48109, U.S.A.

Received September 29, 1983

\section{Introduction}

None of the naked metal cluster polyanions reported so far, such as $\mathrm{Sn}_{9}{ }^{4-}[1], \mathrm{Sb}_{7}{ }^{3-}[2], \mathrm{Sn}_{4}{ }^{2-}$ [3], $\mathrm{Sn}_{5}{ }^{2-}$ [4], $\mathrm{Sn}_{8} \mathrm{Tl}^{5-}$ [3], $\mathrm{Sn}_{9} \mathrm{Cre}_{\mathrm{x}}{ }^{4-}(\mathrm{x}=0-9)$ [3] contain transition metal atoms. These species have been either isolated in solid state through the use of cryptate ligands in amine solvents or very recently for $\mathrm{Sn}_{9}{ }^{4-}$ as $\left[\mathrm{K}(\mathrm{HMPA})_{2}\right]_{4} \mathrm{Sn}_{9}$ in en/HMPA [5], or studied in solution, e.g. $\mathrm{Sn}_{9-\mathbf{x}} \mathrm{Ge}_{\mathbf{x}}{ }^{4-}$. However, we have shown recently by the syntheses of $\mathrm{K}_{4}\left[\left(\mathrm{PPh}_{3}\right)_{2} \mathrm{PtSn}_{9}\right]$ and $\mathrm{K}_{4}\left[\left(\mathrm{PPh}_{3}\right)_{2} \mathrm{PtPb}_{9}\right]$ [6] that a transition metal can be incorporated into a metal cluster polyanion if it is bonded to exocluster ligands, in close parallelism with heteroborane chemistry [7]. In this communication we wish to report the new triheteronuclear metal cluster polyanions, $\mathrm{Na}_{5}$ $\left[\mathrm{L}_{2} \mathrm{PtTISn}_{8}\right]$ and $\mathrm{Na}_{5}\left[\mathrm{~L}_{2} \mathrm{PdTISn}_{8}\right]$. These react quickly to pick up another $\mathrm{Sn}$ atom, probably from a solid phase, liberating the formally $\mathrm{Tl}^{-}$to yield the species $\mathrm{Na}_{4}\left[\mathrm{~L}_{2} \mathrm{PtSn} n_{9}\right]$ and $\mathrm{Na}_{4}\left[\mathrm{~L}_{2} \mathrm{PdSn}_{9}\right]$, this latter species being previously unreported in the literature.

\section{Experimental}

Solutions of $\mathrm{K}_{4}\left[\mathrm{Sn}_{9}\right], \mathrm{Na}_{4}\left[\mathrm{Sn}_{9}\right]$ and $\mathrm{Na}_{5}\left[\mathrm{TlSn}_{8}\right]$ were obtained by extracting alloys of compositions $\mathrm{KSn}_{2}, \mathrm{NaSn}_{2.25}$ and $\mathrm{NaSnTl}_{1.5}$ as previously described $[3,6,8]$. The complexes $\mathrm{Pt}\left(\mathrm{PPh}_{3}\right)_{4}$ and $\mathrm{Pd}\left(\mathrm{PPh}_{3}\right)_{4}$ were synthesized following literature procedures. Ethylenediamine(en) had been dried with $\mathrm{Na}$ /benzophenone and stored under vacuum.

All syntheses were conducted in effectivcly the same way. The reaction $H$ cell is schematically indi-

\footnotetext{
*Author to whom correspondence should be addressed.

+Permanent address: Departament de Química Inorgànica, Universitat Autònoma de Barcelona, (Bellaterra), Barcelona, Spain.

${ }^{++}$Deceased 11 May 1981.
}

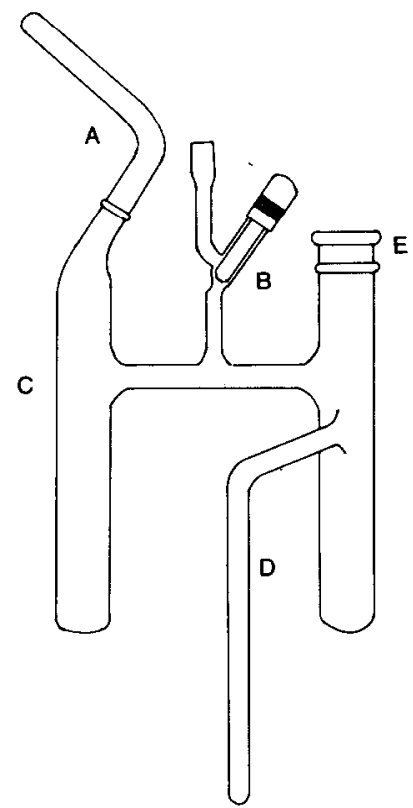

Fig. 1. Schematic representation of the $H$ cell. $A$, tiptube; $B$, stopcock, teflon valve; $C, H$ cell; $D$, NMR tube; $E$, stopper.

cated in Fig. 1. The synthesis of $\mathrm{Na}_{4}\left[\mathrm{~L}_{2} \mathrm{PdSn} n_{9}\right]$ was as follows:

In a glove box filled with pre-purified dinitrogen, $0.3 \mathrm{~g}$ of $\mathrm{NaSn}_{2,25}\left(0.26\right.$ mmols of $\left.\mathrm{Sn}_{9}{ }^{4-}\right)$ were placed in the left arm of the $\mathrm{H}$ cell and $0.3 \mathrm{~g}$ of $\mathrm{Pd}\left(\mathrm{PPh}_{3}\right)_{4}$ $(0.26 \mathrm{mmols})$ in the tip tube. Thoroughly dried en $(10 \mathrm{ml})$ were added to the left arm, and after assembl. ing, the $\mathrm{H}$ cell was taken out of the glove box. Vacuum (0.01 torr) was applied through the stopcock and the ccll stored for 10 days at room temperature to allow the alloy to dissolve. The contents of the tip tube were added to the deep orange-red solution of $\mathrm{Na}_{4}$ $\left[\mathrm{Sn}_{9}\right]$. After a few hours a progressive darkening of the solution was observed. When no more color change was apparent the dark brown solution was carefully transferred to the other arm of the cell and an appropriate fraction of it to the NMR tube which was later torch-sealed.

\section{Discussion}

The conversion of $\mathrm{Na}_{5}\left[\mathrm{~L}_{2} \mathrm{PtTlSn}_{8}\right]$ (I) and $\mathrm{Na}_{5}-$ [ $\left.\mathrm{L}_{2} \mathrm{PdTlSn}_{8}\right]$ (IV) into $\mathrm{Na}_{4}\left[\mathrm{~L}_{2} \mathrm{PtSn}_{9}\right]$ (II) and $\mathrm{Na}_{4}$ [ $\left.\mathrm{L}_{2} \mathrm{PdSn}_{9}\right](\mathrm{V})$, as will be discussed later, poses serious difficulty to a solid state study of the former species. However, the nuclear magnetic properties of the participating elements provide information on the composition and behaviour of the clusters. We have used ${ }^{119} \mathrm{Sn}-\mathrm{NMR}$ spectroscopy to study these 
TABLE I. NMR Spectral Data for the Metal Clusters. ${ }^{\text {a }}$

\begin{tabular}{lllllll}
\hline Compound & & $\delta(\mathrm{ppm})$ & $\mathrm{J}_{119} \mathrm{Sn}-{ }^{205} \mathrm{Tl}$ & $\mathrm{J}_{119} \mathrm{Sn}-{ }^{175} \mathrm{Pt}$ & $\mathrm{J}_{119} \mathrm{Sn}-{ }^{11} \mathrm{Sn}$ & $\mathrm{Ref.}$ \\
\hline $\mathrm{Na}_{5}\left[\mathrm{~L}_{2} \mathrm{PtTlSn}_{8}\right]$ & (I) & -744 & $1451(\mathrm{~Hz})$ & $1500(\mathrm{~Hz})$ & $36.3(\mathrm{~Hz})$ & This work \\
$\mathrm{Na}_{4}\left[\mathrm{~L}_{2} \mathrm{PtSN}_{9}\right]$ & (II) & -753 & & 1554 & 95.2 & This work \\
$\mathrm{K}_{4}\left[\mathrm{~L}_{2} \mathrm{PtSn}_{9}\right]$ & (III) & -736 & & 1544 & 79.0 & 6 \\
$\mathrm{Na}_{5}\left[\mathrm{~L}_{2} \mathrm{PdTlSn}_{8}\right]$ & (IV) & -745 & 1418 & & 51.0 & This work \\
$\mathrm{Na}_{4}\left[\mathrm{~L}_{2} \mathrm{PdSn}_{9}\right]$ & (V) & -755 & & & 39.0 & This work \\
$\mathrm{Na}_{4}\left[\mathrm{Sn}_{9}\right]$ & & -1230 & & 254.0 & 8 \\
$\mathrm{Na}_{5}\left[\mathrm{Sn}_{8} \mathrm{Tl}\right]$ & & -1167 & 793 & 410 & 3 \\
\hline
\end{tabular}

${ }^{a}$ Chemical shifts are referred to tetramethyl tin (TMT). Upfield chemical shift values from TMT are designated negative.

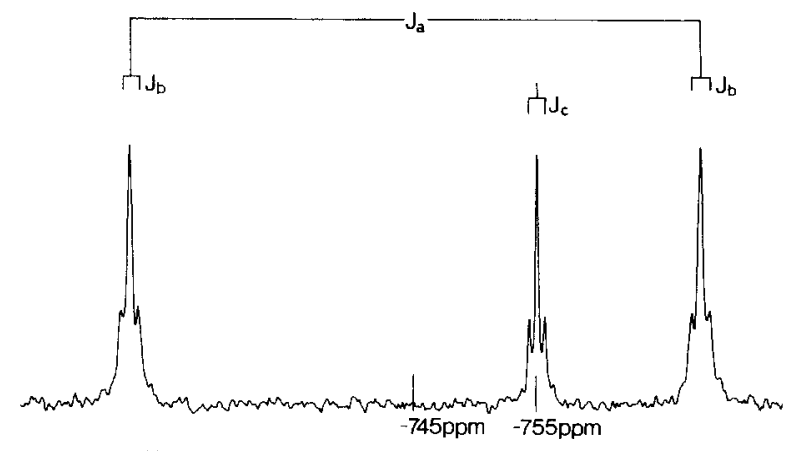

Fig. 2. ${ }^{119} \mathrm{Sn}-\mathrm{NMR}$ spectrum of the mixture $\mathrm{Na}_{5}\left[\mathrm{~L}_{2}-\right.$ $\left.\mathrm{PdTlSn}_{8}\right](\mathrm{IV})$ and $\mathrm{Na}_{4}\left[\mathrm{~L}_{2} \mathrm{PdSn}_{8}\right](\mathrm{V}) ; \mathrm{Ja} \equiv \mathrm{J}_{119} \mathrm{Sn}_{,}{ }^{205,203} \mathrm{Tl}$ $\mathrm{Jb} \equiv \mathrm{J}_{119} \mathrm{Sn}-{ }^{117} \mathrm{Sn}(\mathrm{IV}) ; \mathrm{Jc} \equiv{ }^{119} \mathrm{Sn}-{ }^{117} \mathrm{Sn}(\mathrm{V}) ;$ after one month of mixing the reactants.

clusters, as it has been proven very useful in related $[3,6,8]$ and non-related compounds [9-11].

Addition of $\mathrm{Pt}\left(\mathrm{PPh}_{3}\right)_{4}$ to a solution of $\mathrm{Na}_{5}\left[\mathrm{Sn}_{8} \mathrm{Tl}\right]$ in en causes a slow but gradual change of the solution from deep orange-red to dark brown. The ${ }^{119} \mathrm{Sn}-\mathrm{NMR}$ spectrum of the latter solution displays at -744 ppm a doublet of triplets $(1: 4: 1)$ with each component of the triplet showing fine structure. This kind of spectrum is in accordance with a fluxional cluster of formulation $\mathrm{L}_{2} \mathrm{PtTlSn}_{8}{ }^{5-}$ (I).

In addition another triplet $(1: 4: 1)$ of quintuplets $(0.06: 0.325: 1.0: 0.325: 0.06)^{*}$ is observed in the spectrum at $-7.53 \mathrm{ppm}$ assigned by comparison, to the previously described $\mathrm{L}_{2} \mathrm{PtSn}_{9}{ }^{4-}$ (II-III) cluster [6].

In similar fashion, addition of $\mathrm{Pd}\left(\mathrm{PPh}_{3}\right)_{4}$ to a solution of $\mathrm{Na}_{4}\left[\mathrm{Sn}_{8} \mathrm{Tl}\right]$ also produces a darkening of the solution. The ${ }^{119} \mathrm{Sn}-\mathrm{NMR}$ spectrum of this solution (Fig. 2) displays a doublet of quintuplets at -745 ppm and a quintuplet at $-755 \mathrm{ppm}$ which are assigned to $\mathrm{Na}_{5}\left[\mathrm{~L}_{2} \mathrm{PdTISn}_{8}\right]$ (IV) and $\mathrm{Na}_{4}\left[\mathrm{~L}_{2} \mathrm{PdSn}_{9}\right]$ (V), respectively.

Further evidence that supports the assignment of compound (V) was obtained by reacting $\mathrm{Pd}\left(\mathrm{PPh}_{3}\right)_{4}$ with a solution of $\mathrm{Na}_{4}\left[\mathrm{Sn}_{9}\right]$ in en, paralleling the reaction of $\mathrm{Pt}\left(\mathrm{PPh}_{3}\right)_{4}$ with $\mathrm{K}_{4}\left[\mathrm{Sn}_{9}\right]$ to give III [6]. The ${ }^{119} \mathrm{Sn}-\mathrm{NMR}$ of the solution displayed a quintuplet, with $\delta(119-\mathrm{Sn})$ and $\mathrm{J}_{119} \mathrm{Sn}-{ }^{117} \mathrm{Sn}$ being the same as these for compound $\mathrm{V}$.

It is interesting to note that in the reactions of both $\mathrm{Pd}\left(\mathrm{PPh}_{3}\right)_{4}$ and $\mathrm{Pt}\left(\mathrm{PPh}_{3}\right)_{3}$ with $\mathrm{Na}_{5}\left[\mathrm{Sn}_{8} \mathrm{Tl}\right]$, the relative concentrations of the resulting products vary as a function of time. Within a day after initiation of the reaction, the concentration of the diheteronuclear species (Pt case) rose until it exceeded that of the trihctcronuclear. The conversion process was faster for the platinum system, for which one week after mixing no triheteronuclear species could be detected by ${ }^{119} \mathrm{Sn}-\mathrm{NMR}$, whereas in the $\mathrm{Pd}$ case both species still existed in comparable concentrations at the end of a month. We believe that the triheteronulcear species form quickly and then slowly react with a $\mathrm{Na}-\mathrm{Sn}$ phase, freeing the $\mathrm{Tl}$ and forming the diheteronuclear species.

Due to a partial overlap of the ${ }^{119} \mathrm{Sn}-\mathrm{NMR}$ absorptions of compounds I and IV (see Fig. 2) the number of $\mathrm{Sn}$ atoms in the cluster cannot be calculated exactly from the intensity data and must be inferred by analogy to the better established $\mathrm{L}_{2} \mathrm{PtSn}_{9}{ }^{4-}$ and $\mathrm{L}_{2}$. $\mathrm{PdSn}_{9}{ }^{4-}$ clusters. It is known that ${ }^{119} \mathrm{Sn}$ chemical shifts usually parallel electronegativities and good

\footnotetext{
* This pattern arises because of $\mathrm{J}_{119} \mathrm{Sn}^{117} \mathrm{Sn}$ coupling. Calculations based on abundances of 8.58 and $7.61 \%$ for ${ }^{119} \mathrm{Sn}$ and ${ }^{117} \mathrm{Sn}$ respectively have been carried out. See R. W. Rudolph, R. C. Taylor and D. C. Young, 'Fundamental research in Homogeneous Catalysis'. M. Tutsui, Ed., Plenum Press, New York, 1979, pp. 997-1005.

The calculated relative intensities of the multiplet pattern vary significantly with the size of the cluster; e.g. the five central lines for a 8.9 and 10-atom cluster are calculated to be $0.034: 0.276: 1.000: 0.276: 0.034$, and $0.044: 0.311$ : $1.000: 0.311: 0.044$, and $0.056: 0.345: 0.056$, respectively. Because of the small $J_{119} \mathrm{Sn-117}$ Sn coupling, some overlapping of signals takes place, which favors the smaller ones.
} 
chemical shift-charge correlations have been found in the series of clusters $\mathrm{Sn}_{9-\mathrm{x}} \mathrm{Pb}_{\mathrm{x}}{ }^{4-}(\mathrm{x}=0-9)$ and $\mathrm{Sn}_{4}{ }^{2-}[3]$. In addition we have observed that replacement of a $\mathrm{L}_{2} \mathrm{Pt}$ group by a $\mathrm{L}_{2} \mathrm{Pd}$ group does not change significantly the $\delta(119-\mathrm{Sn})$ of a $\mathrm{L}_{2} \mathrm{MSn}_{9}{ }^{4-}$ cluster, and the same is to be expected in the isoelectronic $\mathrm{L}_{2} \mathrm{MSn}_{8} \mathrm{TT}^{5-}$ series.

In going a step further in this reasoning we see that $\mathrm{Sn}_{9}{ }^{4-}$ and $\mathrm{Sn}_{8} \mathrm{Tl}^{5-}$ are isoelectronic and $\delta(119-\mathrm{Sn})$ are very close at $-1230 \mathrm{ppm}$ and $-1167 \mathrm{ppm}$, so that similar chemical shifts would be expected for $L_{2}$ $\mathrm{MSn}_{9}{ }^{4-}$ and $\mathrm{L}_{2} \mathrm{MSn}_{8} \mathrm{Tl}^{5-}$ clusters, as is in fact the case $\left(\cong-750 \mathrm{ppm}\right.$ for $\mathrm{L}_{2} \mathrm{MSn}_{9}{ }^{4-}$ and $\cong-740 \mathrm{ppm}$ for $\mathrm{L}_{2} \mathrm{MSn}_{8} \mathrm{Tl}^{5-}$ (see Table I). This is what would be expected by comparison with the reactions of $\mathrm{Sn}_{9}{ }^{4-}$ and $\mathrm{Pb}_{9}{ }^{4-}$ where the initial number of $\mathrm{Sn}$ or $\mathrm{Pb}$ atoms in the cluster remains constant [6].

The ${ }^{31} \mathrm{P}$ NMR spectra of all solutions are very similar and display only one signal, assigned to free $\mathrm{PPh}_{3}$. In a few cases, a very low intensity signal was observed in addition to that of $\mathrm{PPh}_{3}$. Based on the results we obtained with the $\left[\mathrm{L}_{2} \mathrm{PtSn}_{9}\right]^{4-}$ species, we believe that the $\mathrm{PPh}_{3}$ ligands have been substituted by the less bulky en.

The similarity of ${ }^{119} \mathrm{Sn}-\mathrm{NMR}$ chemical shifts for these clusters, and the ${ }^{31} \mathrm{P}$ NMR results for $\left(\mathrm{PPh}_{3}\right)_{2} \mathrm{PtSn}_{9}$ [6] indicate that the transition metalligand moiety behaves in the same way in all species, contributing two electrons to the bonds within the cluster. Consequently, $\mathrm{L}_{2} \mathrm{Pt}$ or $\mathrm{L}_{2} \mathrm{Pd}$ moieties, where $L$ is a two electron ligand, are expected.

\section{Summary}

A transition metal can be incorporated into a homonuclear naked metal cluster if it is bonded to the appropriate ligands, yielding in these cases diheteronuclear cluster species (eqns. 1,2).

$$
\begin{aligned}
& \mathrm{Pt}\left(\mathrm{PPh}_{3}\right)_{4}+\mathrm{Sn}_{9}{ }^{4-} \stackrel{\text { en }}{\longrightarrow} \mathrm{L}_{2} \mathrm{PtSn}_{9}{ }^{4-} \\
& \mathrm{Pd}\left(\mathrm{PPh}_{3}\right)_{4}+\mathrm{Sn}_{9}{ }^{4-} \stackrel{\text { en }}{\longrightarrow} \mathrm{L}_{2} \mathrm{PdSn}_{9}{ }^{4-}
\end{aligned}
$$

Triheteronuclear cluster species have been obtained when the zero valent transition metal complexes were reacted with $\mathrm{Sn}_{8} \mathrm{Tl}^{5-}$. These species react further, probably with a Sn-containing phase to yield the diheteronuclear species (faster in the Pt than in the Pd case) (eqns. 3, 4).

$$
\begin{array}{r}
\mathrm{Pt}\left(\mathrm{PPh}_{3}\right)_{4}+\mathrm{Sn}_{8} \mathrm{Tl}^{5-} \stackrel{\text { en }}{\longrightarrow} \mathrm{L}_{2} \mathrm{PtTlSn}_{8}{ }^{5-} \stackrel{\text { 'Sn' }}{\longrightarrow} \\
\mathrm{L}_{2} \mathrm{PtSn}_{9}{ }^{4-} \\
\mathrm{Pd}\left(\mathrm{PPh}_{3}\right)_{4}+\mathrm{Sn}_{8} \mathrm{Tl}^{5-} \stackrel{\text { en }}{\longrightarrow} \mathrm{L}_{2} \mathrm{PdTISn}_{8}{ }^{5} \stackrel{\text { 'Sn' }}{\longrightarrow} \\
\mathrm{L}_{2} \mathrm{PtSn}_{9}{ }^{4-}
\end{array}
$$

\section{Acknowledgements}

FT thanks the Spanish Ministerio de Universidades e Investigación for a grant. We are indebted to Dr. Robert Cooper Taylor (University of Michigan) for advice and consultation. This work was supported in part by the National Science Foundation through Grant CHE 7927146 A01, whose assistance is gratefully acknowledged.

\section{References}

1 J. D. Corbett and P. A. Edwards, I. Am. Chem. Soc., 99, 3313 (1977).

2 J. D. Corbett, D. G. Adolphson, D. J. Merryman, P. A. Edwards and F. J. Armatis, J. Am. Chem. Soc., 97, 6267 (1975).

3 R. W. Rudolph, W. L. Wilson and R. C. Taylor, J. Am. Chem. Soc, 103, 2480 (1981)

4 P. A. Edwards and J. D. Corbett, Inorg. Chem., 16, 903 (1977).

5 R. G. Teller, L. J. Krause and R. C. Haushalter, Inorg. Chem., 22, 1809 (1983).

6 F. Teixidor, M. L. Luetkens, Jr. and R. W. Rudolph, $J$. Am. Chem. Soc., 105, 149 (1983).

7 See for instance, R. N. Grimes, 'Carboranes', Academic Press, 1970.

8 R. W. Rudolph, W. L. Wilson, F. Parker, R. C. Taylor and D. C. Young, J. Chem. Soc., I00, 4629 (1978).

9 R. J. Goodfellow and I. R. Herbert, Inorg. Chim. Acta, 65, L161 (1982).

10 A. Albinati, R. Naegeli, K. H. A. Ostoja Starzewski, P. S. Pregosin and H. Rüegger, Inorg. Chim. Acta; 76, L231 (1983).

11 M. C. Grossell, R. P. Moulding and K. R. Seddon, Inorg. Chim. Acta, 64, L275 (1982). 